\title{
The Invisible Carers
}

\section{Framing Domestic Work(ers) in Gender Equality Policies in Spain}

\author{
Elin Peterson
}

UNIVERSIDAD COMPLUTENSE DE MADRID

ABSTRACT This article explores how paid domestic work is framed in state policies and discourses, drawing upon theoretical discussions on gender, welfare and global care chains. Based on a case study of the political debate on the 'reconciliation of personal, family and work life' in Spain, the author argues that dominant policy frames relate gender inequality to women's unpaid domestic work and care, while domestic workers are essentially the invisible 'other'. Empowering and disempowering frames are discussed; domestic workers are mainly constructed as a solution to the care problem and only marginally as subjects and rights-holders. The overall aim is to examine how public policies legitimize and (re)produce social inequalities related to gender, class and nationality.

KEY WORDS domestic workers $\bullet$ frame analysis $\bullet$ gender equality policies

$\bullet$ reconciliation $\bullet$ Spain

\section{INTRODUCTION}

This article focuses on state discourses surrounding domestic workers in debates on gender equality and care in Spain. Drawing on theories on gender, welfare states and global care chains, I aim to problematize some of the assumptions and contradictions embedded in gender equality policies.

While women's unpaid domestic work and care has been recognized as a central question in feminist thought and has been debated by the feminist movement, women's paid domestic work has remained marginal in feminist theory and practice. Recently, theories on 'global care chains' and the 'international transfer of caretaking' (Ehrenreich and Hochschild, 2003; Salazar Parreñas, 2001) have raised questions about different forms of

European Journal of Women's Studies Copyright (C) 2007 SAGE Publications (Los Angeles, London, New Delhi and Singapore), 1350-5068 Vol. 14(3): 265-280; http:/ / ejw.sagepub.com DOI: 10.1177/1350506807079014 
social inequality and divisions among women. Studies have demonstrated how migrant women from the third world are increasingly employed by private households in the first world to do the 'dirty work' (Anderson, 2000). Researchers have highlighted the exploitative conditions of the work, the asymmetrical power relations between workers and employers and the racist stereotypes that underpin the employment of certain ethnic groups and nationalities ${ }^{1}$ (Anderson and Phizacklea, 1997; Lutz, 2002; Malgesini Rey et al., 2004).

Based on a case study of gender equality policies in Spain, the article constitutes an attempt to map state constructions of domestic work(ers). ${ }^{2}$ Women's unpaid domestic work has been disputed in the debate on the 'reconciliation of work and family life', ${ }^{3}$ a notion that has become central in Spanish gender equality policies throughout the last decade (Bustelo et al., 2004). While paid domestic work is still a marginal issue on the political agenda, migrant women have come to play a crucial role in providing care in the absence of welfare provision. The article draws on a frame analysis of central public policy documents such as equality plans, laws, law proposals and parliamentary debates from the period 1995 to 2006. Texts elaborated by trade unions, a domestic workers' association and the national Women's Agency (Instituto de la Mujer) are also analysed.

The article aims to contribute to a discussion on how, in specific contexts, public policies and discourses surrounding domestic work and care (re)produce social inequalities linked to gender, class and nationality. Further, the analysis discusses both disempowering and empowering ways of framing paid domestic work.

\section{FRAMING 'GENDER EQUALITY'}

The article uses the methodological framework of frame analysis ${ }^{4}$ (see Verloo, 2005). The approach is based on a critical perspective on established knowledge with a focus on language and the processes by which meanings and categories are constituted in specific cultural and historical contexts. Frames and discourses have social and material consequences as they are contingent articulations of elements that reproduce or challenge hegemonic representations of the world. Mapping the way groups are constructed into 'we' and 'the others' can give us clues about what is being excluded and what social consequences this may have (Winther and Phillips, 1999).

Frame analysis is concerned with identifying dominant and contesting representations, and the contradictions within them, in the discourses of the actors involved in the construction of policy problems (Rein and Schön, 1993; Snow and Benford, 2000). A policy frame can be defined as 'an organizing principle that transforms fragmentary or incidental information into a structured and meaningful policy problem, in which a solution 
is implicitly or explicitly enclosed' (Verloo, 2005: 20). The analysis raises questions of whose representations get heard and whose voices remain unheard, and absences in the political agendas are considered significant (Bacchi, 1999).

Gender equality has been conceptualized in multiple ways by feminist scholars as well as in public policies. The article examines precisely the framing of gender equality rather than presupposing a fixed meaning of the concept. Judith Squires (1999) outlines how feminist analysis has moved from focusing on equality between women and men, to highlighting gender differences and then to emphasizing gender diversity and diversity politics. Nancy Fraser (1997) reconstructs the history of debates in the feminist movement, identifying a shift towards a focus on differences among women and multiple intersecting differences. Chandra Talpade Mohanty (1994) has shown how western feminist thought has constructed the third world woman as the 'other'; as a passive, victimized and homogenized object rather than the subject of agency, in contrast to the modern, educated and liberated western woman. Definitely, white, middle-class, heterosexual feminism has been widely criticized for hegemonic representation and marginalization.

\section{GENDER, WELFARE STATES AND GLOBAL CARE CHAINS}

The welfare state has been considered a central institution in the construction of gendered power relations and feminist reworkings and critiques of welfare state typologies have stimulated substantial literature (Daly, 2000; Lewis, 1993; Sainsbury, 2000). Jane Lewis's breadwinner model has exposed the normative prescription of the sexual division of labour in welfare policies. The breadwinner model has been developed as an instrument for comparative analysis and has generated many studies on the differences and similarities between welfare state regimes. A weakness of such comparative studies is that they often overlook the ways in which hegemonic discourses privilege some women over others and do not sufficiently explore differences within states. Post-structural feminist accounts of welfare policies have emphasized the heterogeneous and differentiated nature of the state. The differentiated state can have both empowering and disempowering effects on women (Kantola and Dahl, 2005). Julia O'Connor et al. (1999) argue that public policies have encouraged mothering in the home and breadwinning for men for a privileged race/ethnicity or class, while rejecting other groups such support. Fiona Williams's (1995) analysis of the welfare state shows how, in the context of the hegemony of the white breadwinner model, certain groups get constructed as 'other' on the basis of a supposed racial, ethnic or cultural difference. 
All EU states have embraced neoliberal policies to a varying extent and social policy has been increasingly subordinated to the demands of maintaining competitiveness and the promotion of 'flexible' labour markets (Walby, 1999). A two-tier labour market has been established, one for EU citizens and one for nationals of third countries who provide cheap and flexible labour. The global economy involves a process where women from the third world are employed by households in the first world. The growing literature on global care chains sets domestic workers in the centre of attention, emphasizing how care work is related to divisions among women (Anderson, 2000; Anthias and Lazaridis, 2000; Ehrenreich and Hochschild, 2003; Kofman, 2001; Salazar Parreñas, 2001). Bridget Anderson sheds light on how feminism entails contradictory thoughts on domestic work. Feminists have often considered domestic work as a common burden imposed on women by patriarchy, not asking questions on how this work is intertwined with categories such as class and race. Yet, the employment of domestic workers in private households is a 'crucial means through which asymmetrical race and class relations among women are structured' (Bakan and Stasiulis, 1995: 303). Attention to intersecting differences tells us that the sexual division of labour cannot be seen as universally applicable without contextualization (Mohanty, 1994).

\section{LINKING ‘RECONCILIATION' POLICIES AND PAID DOMESTIC WORK IN SPAIN}

The key role attributed to the family, and thereby women, in Spanish welfare policies has been analysed and criticized by feminist scholars (Carrasco et al., 1997; Threlfall et al., 2005). Spain relies to a large extent on informal unpaid care work, but paid care work in private households is gradually becoming more common (Anttonen, 2005). The characteristics of the Spanish welfare state, the ageing population, the increasing participation of women in the labour market and the unequal distribution of domestic and care work between women and men are features interconnected with the expansion of domestic service as a field of employment (Martínez Buján, 2005).

The conservative government of the Partido Popular (1996-2004) made 'reconciliation of work and family life' a key issue on the political agenda. Family responsibility, non-governmental provision and voluntary work were emphasized in welfare issues (Valiente, 2001). The policies that aimed to address the 'reconciliation' were oriented towards women's managing of paid and unpaid work (Moreno and Salido, 2005). The current Socialist government (2004-) has declared gender equality a priority and the lack of a nationwide network of care services has been addressed; the Law for the Promotion of Personal Autonomy and Attention to Persons in Situation of 
Dependency was adopted by the parliament on 30 November 2006. The Organic Law for De Facto Equality between Women and Men, which is expected to come into force in March 2007, treats the 'reconciliation of personal, family and work life' as a central issue. ${ }^{5}$

Still, the 'reconciliation' policies show great deficiencies when it comes to public services and infrastructures related to the care of children, elderly and disabled citizens. Spain is one of the countries of the EU that spends the least on support of families and young children; only 0.5 percent is dedicated to such expenditure in 2002 while the average is 2.2 percent $^{6}$ (Moreno and Salido, 2005). At the same time, there is a lack of care services for the elderly in a context of an ageing population; only 3.14 percent of the elderly over 65 years have access to home help and residencies are available to 3.78 percent of this population (Martínez Buján, 2005).

The strategies to manage combining employment and care are infinite. Women's micro-solidarity networks play a crucial role (Carrasco et al., 1997; Moreno and Salido, 2005; Threlfall et al., 2005; Valiente, 2001). Reliance on family help is an extended practice in general and for childcare it is common to depend on grandmothers (Fernández Cordón and Tobío Soler, 2005). Celia Valiente (2001) argues that there is a mistrust of institutionalization of childcare, with associations of childcare centres as the worst option. Notwithstanding, studies indicate that the expectations of women's unpaid work within the family can no longer sustain the weight placed upon it (Anttonen, 2005; Martínez Buján, 2005; Stark and Regnér, 2002).

In the Mediterranean countries, an important strategy is to use the services of the 'maid industry' (Anderson, 2000; Anthias and Lazaridis, 2000; Kofman, 2001). In Spain, the insertion of migrants in domestic work can to a certain extent be seen as a replacement of the earlier internal migration of women from poor rural backgrounds to the big cities as maids for well-off families (King and Zontini, 2000). In recent years, though, the supply of domestic workers has been promoted by the state through its immigration policies. The successive modifications of the foreigners' law have established a policy designed at meeting demographic, labour and economic needs, and the continuing incorporation of migrants in domestic work has been promoted through a quota system (Anthias and Lazaridis, 2000; Lutz, 2002). In the extraordinary regularization process carried out in Spain in 2005 by the Spanish Ministry of Labour and Social Affairs, 32 percent of the applications were related to employment in the domestic service sector, and 83 percent of the workers within this sector were women. Studies also show that caring for the elderly in private homes has turned into an ever more frequent field of work among migrant women (Martínez Buján, 2005).

It is noteworthy that the employment of domestic workers is crucially a question of class. A study on coping strategies of working mothers indicates that 54.5 percent of women of high socioeconomic level, 29.5 percent 
of women of middle level and 11.5 percent of the lower level count on the assistance of domestic workers ${ }^{7}$ (Fernández and Tobío, 2005).

The Spanish legal framework constructs paid domestic work as 'different' from 'normal' types of work (Colectivo IOÉ, 2001). This is reflected in the social security system, in the Special Regime of Domestic Workers, which regulates employment in domestic service and provides far less protection than the General Regime. It does not include unemployment benefits, written contracts are only required when the job exceeds 80 hours a month, professional illnesses and accidents are not recognized, working hours are 'flexible', etc. What is more, the norms of the Special Regime are often circumvented and migrant workers who are included in the regime are often not aware of their rights (Gavanas et al., 2007).

Then again, domestic work often forms part of the submerged economy. For undocumented female migrants, jobs other than in informal domestic service are hard to find and these women are especially vulnerable to abuse (Kofman, 2001). Yet, it should be noted that in Spain, in contrast to other European countries like Germany and the UK, rights to health care and education are recognized regardless of legal status (Malgesini Rey et al., 2004).

\section{FRAMING DOMESTIC WORK IN GENDER EQUALITY POLICIES: THE `RECONCILIATION’ DEBATE}

In the context of the EU, the concept of reconciliation of work and family life was introduced in the 1970s and was linked to the idea of sharing responsibilities in productive and reproductive work between women and men. Nowadays, the issue of reconciliation forms part of the dominant language of the EU, but it has gradually become associated with liberal market solutions and less with the problem of gender inequality (Stratigaki, 2004). In Spain, the concept was introduced in the Third Equality Plan (1997-2000), and in the Fourth Equality Plan (2003-6) it became one of the central issues. Noticeably, 'reconciliation' has evolved into a recurrent notion that shapes the debates on gender equality, employment and social policy.

Central policy documents from the period of the government of Partido Popular represent care issues as a 'working mother's matter'. ${ }^{8}$ The notion of 'reconciliation' transmitted by the policy documents involves a normative image of women as mothers and workers. Care is often represented as a secondary problem; the principal problem is women's incorporation into the labour market. The solution proposed is to support and encourage working mothers so that they are able to combine work and family life. Men constitute the implicit norm group as individuals who do not need to reconcile work and family life. A crucial text is the Reconciliation 
Law, ${ }^{9}$ which illustrates how the reconciliation debate is closely linked to motherhood and rights related to maternity leave. Spain has one of the lowest birth rates in Europe, and the focus on motherhood overshadows other aspects such as the care for the elderly.

Women are depicted as a homogeneous group supposedly sharing the same problems of caretaking responsibilities, and yet, the measures favour certain groups of women. In January 2003, the government introduced a new tax measure that gives working mothers the possibility to apply for a subsidy of $€ 100$ per month for childcare for each child under three years of age. The objective is to compensate mothers on the grounds that motherhood implies a 'social and labour related cost for women'. However, the reform excludes many women from benefits: $:^{10}$ unemployed women, workers in the submerged economy and housewives. ${ }^{11}$ The spirit of the law is not concerned with class inequalities or universal citizen rights. The subsidy reproduces the normative assumption of women as caregivers, while privileging the interests of certain groups of women, especially middle- and upper-class women.

The Equality Plans promote market-friendly solutions in terms of flexibility of work in order to make reconciliation of work and family life feasible. Consequently, there is an emphasis on encouraging different forms of flexible work, implicitly 'feminine work':

Equal opportunity between women and men requires, first of all, the creation of more and better employment for women. (The Conservative Party's electoral programme for 2004, chapter on equality for women $)^{12}$

The statement indicates that gender equality is seen as conditioned by the creation of more employment for women, which implies an understanding of women's employment as different from men's employment. Society needs to create more employment that fits 'women's needs'. Sexbased discrimination and segregation in the labour market and precarious work are not represented as problems.

The Socialist government (2004-) has, to a certain extent, articulated a policy discourse that questions the association of domestic work and care with 'women's work'. Discrimination in the labour market due to the construction of women as caregivers and the lack of co-responsibility of men are acknowledged problems. Care is represented as a public problem and the solutions are related to improved welfare policies and legislative changes.

The Organic Law for De Facto Equality between Women and Men treats the issue of 'reconciliation of personal, family and work life' as a crucial issue. The introduction of an individual right to paternity leave ${ }^{13}$ is represented as the most innovative measure. Although recognizing the role of fathers in care, the right is indeed limited: two weeks of leave. Undeniably, women are still constructed as having the primary responsibility for 
childcare. There is an overall silence on paid domestic work, and domestic workers registered in the Special Regime are the target group of one measure: the right to maternity leave.

The Law for the Promotion of Personal Autonomy and Attention to Persons in Situation of Dependency assigns state responsibility in the provision of care for persons in a situation of dependency. Thereby, the often invisibilized care work enters the political agenda. However, the law has been criticized by feminists ${ }^{14}$ for reproducing the norm of care work as 'women's work' with measures that strive to help women continue caring, in notably precarious conditions. There are also class-related implications of the limits to the principle of universal rights. The great majority of households with low and medium incomes will still have to pay a significant amount for public services. Finally, the law has been said to be unclear on migrants' rights to care services and there is a risk that the law will exclude those who frequently perform care work from the right to be cared for in the future. The types of care given status in the law are 'family care' (also referred to as non-professional) performed by someone in the family, and 'professional care', which involves public services, private companies and profit or non-profit organizations. Domestic workers as conceived in the Special Regime of Domestic Workers constitute an absent figure.

\section{GENDER EQUALITY AND THE INVISIBLE ‘OTHER': PAID DOMESTIC WORK}

Indeed, paid domestic work or domestic workers' rights have not really entered the political agenda on gender equality. In policy discourses surrounding gender equality, the focus falls on women's unpaid care and domestic work. The perpetuation of the sexual division of labour, along divisions of class, race and nationality, by transferring care and domestic work from one woman to another is hardly ever questioned. Domestic workers are rather the invisible 'other':

We have for many years fought for equal rights for men and women, but we ought not to forget an inequality which to me is very important and that is the one existing between women themselves: not all women who find work have a salary that allows them to have someone else working at home. (MP Navarro Garzón, Socialist Party in parliamentary debate, 13 May 2003)

Domestic workers are represented as a solution to women's double workday, although accessible only to more economically privileged women. That this 'someone else' is usually a woman, often of workingclass and migrant background, is disregarded, and the conditions in which these workers enter the sector are ignored. 
There are very few references to paid domestic work in the national Equality Plans; the Third Equality Plan included a measure to 'study' the Special Regime of Domestic Workers and 'evaluate its functioning'. The plan also included the measure to promote the qualifications and training of women in those professions that constitute 'new fields of employment'. A study published by the national Women's Agency (Oso, 1998), however, points at the problem that women's 'liberation' has not gone hand in hand with a restructuring of the sexual division of labour. The study highlights the increase of migrant domestic workers and their role in helping autochthonous women' to reconcile work and family life:

The domestic worker replaces her professional [female] employer in reproductive tasks that neither the state nor the partners share. (Oso, 1998: 196)

\section{Domestic Workers as a Solution to the Spanish Care Problem: A Disempowering Frame}

Domestic workers were set in the centre of the debate on one particular occasion in parliament during the last decade, in a debate in June 2005 on a possible reform of the Special Regime of Domestic Workers of $1985 .{ }^{15}$

The parliamentary debate reveals multiple and contradictory ways of framing paid domestic work. The speakers agreed that the Special Regime is obsolete and discriminatory and that domestic work should be given more dignified conditions. At the same time, some speakers refused to support an improvement in the Special Regime, implying that this would increase the underground economy. The speakers appeared to share the idea that improving the rights of domestic workers would promote 'gender equality' due to the fact that the great majority of the workers are women. Migrant women's situation was also mentioned as it was pointed out that the augmentation of migrant women in the sector of domestic work was creating a new kind of social and economic inequality in Spain and that this would affect the integration of these women and their families in a negative way.

However, the debate indicates that domestic workers' rights are not primary concerns; other, more important issues were noted, as indicated by discourses surrounding the balance of the economy, employment and middle-class families' interests and 'quality of life'. Any reform should by no means imply making the services more expensive for the middle class. At the same time, it was argued that the economic and social welfare of the expanding middle class explained the growing employment of domestic workers. How to satisfy the demands of middle-class families where both men and women work was framed as a central issue. The member of parliament representing Partido Popular argued in favour of 
subsidies to 'big families' (familia numerosa) for employing domestic workers, above all because it would 'create employment opportunities'. Furthermore, it was noted, the rights of domestic workers should by no means put state finances in danger.

We can find different and contradictory interpretations on why paid domestic work is not just another job, but essentially 'different' in its character. Some representations criticized the servitude historically inherent in domestic work, but other representations reproduced the notion of paid domestic work as 'different' in a way that justifies distinctive working conditions:

The necessity of a Special Regime is obvious. On the one hand, the employer is not really an employer but rather a head of family who does not profit in a stringent sense from the work but this assistance covers an apparent need in our society, and the employed person is often used as a substitute when work is not compatible with family life ... we have an employee that offers assistance in a very specific context, at times within a frame of confidence/distrust and familiarity, where not all time of presence is real work, where the framework of rights is relative, and where life and work are intimately connected to the point that one can often not distinguish between them. (MP Tardá I Coma, Catalonian Left Republican Party)

There seems to be a widespread understanding of migrant domestic workers as essential to solve the care problem and to improve the 'reconciliation of work and family life'. At a conference on Gender and Migration, a representative of the regional government of Madrid argued that 'we' should be thankful to the migrants because 'they help Spanish women to harmonize their family and work life'. ${ }^{16}$

None of the MPs intervening in the parliamentary debate referred to the demands of those organizations and associations that work in favour of the rights of domestic workers. The Spanish trade unions have organized several campaigns in favour of the rights of domestic workers, like requesting to equalize the Special Regime for Domestic Workers with the General Regime. Nevertheless, the major trade unions have been criticized for remaining passive in defending the rights of domestic workers. ${ }^{17}$

Likewise, the trade unions sometimes reproduce a disempowering frame for domestic workers. A study carried out by the Unión General de Trabajadores (UGT) in 2003 highlights that domestic services of migrant women constitute a central strategy to improve the reconciliation of work and family life. Even though exploitative working conditions are denounced, a justification of the special conditions of migrant women workers can be perceived in the reference to these, implicitly 'third world' and 'oppressed', women being used to bad conditions from their home countries:

The double burden of the migrant woman is exactly what makes her accept the harsh conditions of domestic workers as live-ins, which she sometimes 
even values as positive since she usually compares them with the conditions in her country of origin. (UGT report 'Immigration and the Work World: Domestic Service', 2003)

\section{Domestic Workers as Subjects and Rights-Holders: An Empowering Frame}

In the context of passive trade unions, other organizations and associations, such as NGOs and religious associations, provide assistance to migrant domestic workers, and a Platform for Associations of Domestic Workers (PATH) has been established. One of the associations within this platform, the Association of [Female] Domestic Workers of Vizcaya is atypical in the sense that it is linked to the feminist movement and engages domestic workers as well as women who have never been working in the sector. The activities go beyond the struggle for better working conditions as the association also aims to raise new questions around the vision of 'gender equality'.

The work of the association consists in informing political and social actors about the situation in the domestic service sector, denouncing exploitative working conditions, as well as offering free legal advice. In recent years, the association has been occupied in elaborating a law proposal to assure dignified working conditions and the treatment of domestic work as just another job, eliminating the Special Regime. The law proposal includes the requirement of written contracts, a maximum 40hour working week, salaries related to the type of work (e.g. care of elderly or cleaning), social security from the first day of work and the right to unemployment benefits and sick leave, etc.

The obstacles in the struggle for domestic workers' rights are multiple, but one important barrier lies at state level. A representative of the association, Isabel Quintana, ${ }^{18}$ says that this is a sector that everybody knows should change and yet it doesn't: 'We should not forget that many institutions do not pressure enough because services are not covered and domestic workers serve as a mattress to conceal all this.' Currently, the limited public resources for care services and the economic limitations of families seem to justify that domestic workers work 'for $€ 500$ a month, 12 hours a day, 7 days a week'.

Domestic workers have also been an absent issue in the feminist movement. Quintana argues that 'we have insisted in the incorporation of women in the work world in equal conditions but we have failed to see to

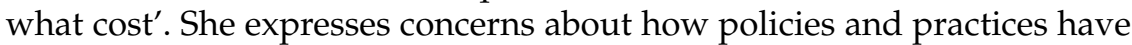
not accomplished the questioning of the gendering of care work and she disputes the focus on employee and employer as a relation between women, arguing that men, as well as women, take advantage of paid domestic work: 
'Our fear is that all this serves to perpetuate that women, with or without a salary, keep doing all the care work.'

\section{CONCLUSIONS}

State policies and discourses can have both empowering and disempowering effects on women. In the Spanish context, dominant policy frames on gender equality both reproduce women as primary caregivers and privilege some women's care dilemmas over others, legitimizing and (re)producing social inequalities related to class and nationality.

Middle- and upper-class national or European women's interests are normative and domestic workers are the invisible 'other' in the sense of passive objects in gender equality policies. Domestic workers are represented as a solution to the care problem or, even, as the solution to women's inequality. The sexual division of labour, to some degree criticized within the gender equality discourse, is rendered unproblematic when it comes to the externalization of domestic work. The rights of domestic workers are represented as subordinate to issues of 'reconciliation', middle-class families' life quality, economic growth and increased employment. The recurrent framing of domestic work as 'different' legitimizes the fact that working conditions in this sector remain linked to its history of colonialism and servitude. Those voices that represent domestic workers' rights as a matter of gender equality are still very marginal in the public debate.

While feminist research has shifted towards a focus on diversity and 'multiple intersecting differences', the lack of such perspectives in Spanish gender equality policies obscures divisions among women so critical in the case of paid care and domestic work.

\section{NOTES}

I would like to thank María Bustelo and Emanuela Lombardo (University Complutense of Madrid) for their helpful comments on earlier versions of this article. I am also grateful to Judith Squires (University of Bristol) and the anonymous referees for their valuable comments.

The article was written within the framework of a PhD grant of the Spanish Ministry of Education and Science (FPU). It has also partly been elaborated thanks to the European research project MAGEEQ (HPSE-CT-2002-00127) and the research project 'Análisis de los marcos interpretativos de las políticas autonómicas de igualdad de género en España' (INT.MUJER-65/04).

1. 'Otherness' in the sense of the racialization of migrant domestic workers has been emphasized in many studies. As paid domestic work enters the political agenda, it is probable that we shall find a similar racialization of migrant workers in policy documents but this will have to be explored in future studies. 
2. Domestic workers perform heterogeneous tasks, summarized by Bridget Anderson (2000) as 'cleaning, cooking and caring'. I use the term 'domestic workers' to refer to workers performing all these kinds of tasks. In Spain, many domestic workers are employed to do care work, but the statistics based on the social security register do not distinguish between domestic tasks and care work; all go under the title 'domestic service' (Martínez Buján, 2005: 96).

3. This concept is explained later in the article, in the part on 'reconciliation' policies in Spain. The analysis of the debate surrounding 'reconciliation of work and family life' partly draws upon research on family policy, carried out within the European research project MAGEEQ (www.mageeq.net).

4. I wish to thank the MAGEEQ research team, within which the critical frame analysis was developed.

5. Important changes in gender equality and family policies have taken place with the Socialist government, e.g. the recognition of various types of families including homosexual marriage and the Law against Gender Violence.

6. Source: Eurostat (2002; cited in Moreno and Salido, 2005).

7. It can be noted that the figure for women of lower socioeconomic background is still quite high compared with other parts of Europe.

8. I here refer to the following documents: Law 39/1999 to Promote Workers' Reconciliation of Family and Work Life (5 November 1999); Law 46/2002 on Partial Reform of Personal Income Tax IRPF (18 December 2002); Third Plan for Equal Opportunities between Women and Men (1997-2000); Fourth Plan for Equal Opportunities between Women and Men (2003-6).

9. Law 39/1999 draws upon the European Community Directives 96/34/EC on parental leave and $92 / 85 / \mathrm{CEE}$ on maternity protection in the labour market.

10. The beneficiaries of this fiscal measure must have a full-time job or be selfemployed and be registered for social security at least 15 days per month. Also women who have part-time jobs working at least 50 percent of the time, and are registered for social security can benefit from the reform. Women who work less than 50 percent of the time will not be able to receive the $€ 100$ per month but a proportional amount can be deducted in their annual tax declaration.

11. Housewives do not benefit from the tax deduction but the law includes a childcare tax reduction for 'families', which means that the childcare of housewives can be offset against tax paid by the husband.

12. Quotations from the texts analysed are my translations.

13. The previous regulation (Law 39/1999) involves the possibility for the mother to transfer part of her 16 weeks' maternity leave to the father.

14. See for example Amaranta, Publication of the Feminist Assembly of Madrid, No. 2 on the dependency law and the crisis of care work.

15. Parliamentary debate, 27 June 2005, on the law proposal presented by the Galician Nationalist Party on the improvement of the protection of the Special Regime of Domestic Workers.

16. 'Las mujeres, protagonistas de la inmigración latinoamericana en España', 29-30 May 2006. Speaker Carlos Clemente, Vice Councillor of Migration and Development Cooperation of the Regional Government of Madrid.

17. Conference on the Domestic Work Sector, 6 May 2006, organized by NGO Cáritas and the Platform for Associations of Domestic Workers. Critique was directed towards the trade unions UGT and CC.OO.

18. Interview with Isabel Quintana, 6 May 2006. 


\section{REFERENCES}

Anderson, Bridget (2000) Doing The Dirty Work? The Global Politics of Domestic Labour. London: Zed Books.

Anderson, Bridget and Annie Phizacklea (1997) Migrant Domestic Workers: A European Perspective, Report for the Equal Opportunities Unit, DGV. Brussels: Commission of the European Communities.

Anthias, Floya and Gabriella Lazaridis, eds (2000) Gender and Migration in Southern Europe: Women on the Move. Oxford: Berg.

Anttonen, Anneli (2005) 'Hacia un mayor cuidado público: cambios en las relaciones y las políticas públicas de cuidado a las personas dependientes', Panorama Social (FUNCAS, Madrid) 2: 8-20.

Bacchi, Carol (1999) Women, Policy and Politics. The Construction of Policy Problems. London: Sage.

Bakan, Abigail B. and Daiva K. Stasiulis (1995) 'Making the Match: Domestic Placement Agencies and the Racialisation of Women's Household Work', Signs 20(21): 303-35.

Bustelo, Maria, Emanuela Lombardo, Raquel Platero and Elin Peterson (2004) Country Study Spain: Family Policy. Vienna: Institut für die Wissenschaften des Menschen.

Carrasco, Cristina Anna Alabart, Maribel Mayordomo and Teresa Montagut (1997) Mujeres, trabajos y políticas sociales: una aproximación al caso español, Report No. 51. Madrid: Ministerio de Trabajo y Asuntos Sociales, Instituto de la Mujer.

Colectivo IOÉ (2001) Mujer, inmigración y trabajo. Madrid: Instituto de Migraciones y Servicios Sociales (IMSERSO).

Daly, Mary (2000) ‘Paid Work, Unpaid Work and Welfare. Towards a Framework for Studying Welfare State Variation', pp. 21-38 in Thomas P. Boje (ed.) Gender, Welfare and the Market: Towards a New Division of Labor. London: Routledge.

Ehrenreich, Barbara and Arlie Russell Hochschild, eds (2003) Global Woman: Nannies, Maids and Sex Workers in the New Economy. New York: Metropolitan Books.

Fernández Cordón, Juan Antonio and Constanza Tobío Soler (2005) 'Conciliar las responsabilidades familiares y laborales: políticas y prácticas sociales', Documento de trabajo 79, Fundación Alternativas.

Fraser, Nancy (1997) Justice Interruptus: Critical Reflections on the 'Postsocialist' Condition. New York: Routledge.

Gavanas, Anna, Constanza Tobío and Fiona Williams (2007) 'Gendered Citizenship and Global Care Chains', in A. Anttonen et al. (eds) Gendering Citizenship in Western Europe: New Challenges for Citizenship Research in a Cross-National Context. Bristol: Policy Press.

Kantola, Johanna and Hanne Marlene Dahl (2005) 'Gender and the State: From Differences between to Differences within', International Feminist Journal of Politics 7(1): 49-70.

King, Russel and Elisabetta Zontini (2000) 'The Role of Gender in the South European Immigration Model', Papers: revista de sociología 60: 35-52.

Kofman, Eleonore (2001) Gender and International Migration in Europe: Employment, Welfare and Politics. London: Routledge.

Lewis, Jane (1993) Women and Social Policies in Europe: Work, Family and the State. Burlington, VT: Edward Elgar.

Lutz, Helma (2002) 'At Your Service Madam! The Globalization of Domestic Service', Feminist Review 70: 89-104. 
Malgesini Rey, Graciela et al. (2004) Transnational Report: Homes, Caretaking, Frontiers. Madrid: Traficantes de Sueños.

Martínez Buján, Raquel (2005) 'El cuidado de acianos: un vínculo entre la inmigración y el envejecimiento', Panorama Social (FUNCAS, Madrid) 2: 86-97.

Mohanty, Chandra Talpade (1994) 'Under Western Eyes: Feminist Scholarship and Colonial Discourses', pp. 196-220 in Patrick Williams and Laura Chrisman (eds) Colonial Discourse and Post-Colonial Theory: A Reader. New York: Columbia University Press.

Moreno, Luis and Olga Salido (2005) 'Welfare and Family in Spain', Revista delle politiche Sociali 4.

O'Connor, Julia, Ann Shola Orloff and Sheila Shaver (1999) States, Markets, Families: Gender, Liberalism and Social Policy in Australia, Canada, Great Britain and the United States. Cambridge: Cambridge University Press.

Oso, Laura (1998) La migración hacia España de mujeres jefas de hogar. Madrid: National Women's Agency.

Rein, Martin and Donald Schön (1993) 'Reframing Policy Discourse', pp. 141-66 in Frank Fisher and John Forester (eds) The Argumentative Turn in Policy Analysis and Planning. Durham, NC: Duke University Press.

Sainsbury, Diane, ed. (2000) Gendering Welfare States. London: Sage.

Salazar Parreñas, Rhacel (2001) Servants of Globalization: Women, Migration and Domestic Work. Stanford, CA: Stanford University Press.

Snow, David A. and Robert D. Benford (2000) 'Framing Processes and Social Movements: An Overview and Assessment', Annual Review of Sociology 26: 611-39.

Squires, Judith (1999) Gender in Political Theory. Cambridge: Polity Press.

Stark, Agneta and Åsa Regnér (2002) 'In Whose Hands? Work, Gender, Ageing and Care in Three EU Countries', Tema Genus, Report 2, University of Linköping.

Stratigaki, Maria (2004) 'The Cooptation of Gender Concepts in EU Policies: The Case of "Reconciliation of Work and Family" ', Social Politics 11: 30-56.

Threlfall, Monica, Christine Cousins and Celia Valiente (2005) Gendering Spanish Democracy. New York: Routledge.

Valiente, Celia (2001) 'Do Political Parties Matter? Do Spanish Parties Make a Difference in Child Care Policies?', pp. 97-114 in Tricia Davis (ed.) Promoting Evidence-Based Practice in Early Childhood Education: Research and its Implications. Amsterdam: JAI Press.

Verloo, Mieke (2005) 'Mainstreaming Gender Equality in Europe. A Critical Frame Analysis Approach', The Greek Review of Social Research (Special issue: Differences in the Framing of Gender Equality as a Policy Problem across Europe): 11-34.

Walby, Sylvia (1999) New Agendas for Women. New York: Palgrave.

Williams, Fiona (1995) 'Race/Ethnicity, Gender, and Class in Welfare States: A Framework for Comparative Analysis', Social Politics 2: 127-59.

Winther Jørgensen, Marianne and Louise Phillips (1999) Discursanalys som teori och metod. Lund: Studentlitteratur.

Elin Peterson is a PhD candidate in political science at the University Complutense of Madrid, Spain. She has worked as a junior researcher in the European research project 'MAGEEQ: Policy Frames and Implementation Problems - The Case of Gender Mainstreaming'. She has also been a visiting research collaborator at the Department of Politics at the University of Bristol, UK. Her research interests include issues of gender, welfare states and globalization, and her work focuses 
especially on the constructions of gender equality and the state in political debates surrounding domestic and care work in Europe. Address: Departamento de Ciencia Política y Administración II, Fac. CC Políticas y Sociología, Universidad Complutense de Madrid, Pozuelo de Alarcón 28223, Madrid, Spain. [email: epeterson@cps.ucm.es] 